\title{
ANALISIS DISPARITAS DAN INTERAKSI SPASIAL DI TIMOR-LESTE
}

\author{
Analysis of the Disparity and Spatial Interaction in Timor - Leste
}

\author{
LUCAS SOARES $^{1 *}$, ERNAN RUSTIADI ${ }^{1}$, DAN SRI MULATSIH ${ }^{1}$ \\ ${ }^{1}$ Program Studi Ilmu Perencanaan Pembangunan Wilayah dan Perdesaan, Institut Pertanian Bogor, Jl. \\ Kamper Lingkar kampus, Level 5 Wing 2 Kampus IPB Darmaga, Bogor 16680; "Penulis korespondensi, \\ e-mail: luberaso0404@gmail.com \\ (Diterima: 1 November 2016; Disetujui: 5 Januari 2017)
}

\begin{abstract}
Spatial planning is a tool to achieve braden goals of development. To support economic development in Timor Leste, it needs an optimal spatial structure planning that supports connectivities between districts through infrastructures network. This research aimed to analyze and explain disparities, interaction and optimal regional spatial structure using variables of infrastructures and public facilities on national and regional/districts/subnational activities center. This research used Scalogram and gravitation modelling analysis. The results showed that there is a high disparity level between districts in Timor-Leste that caused by the lack of public facilities and lack of access to public services. Moreover, the spatial structure interaction between districts are very weak. To cope with those problems, this research suggested the formulation of one national activity center located in the north (Dili) and three Regional (subnational) Activity Center (RAC) located at Ermera in the west, Baucau in the east and Manufahi in the south of Timor-Leste.
\end{abstract}

Keywords: regional disparities, gravitation model, spatial interaction, spatial structure, scalogram

\begin{abstract}
ABSTRAK
Perencanaan spasial wilayah merupakan alat untuk mencapai tujuan umum pembangunan. Perencanaan spasial merupakan prasyarat pembangunan untuk menentukan pusat kegiatan dengan memperhatikan efisiensi interaksi dengan daerah hinterland. Penelitian ini bertujuan menganalisis dan menjelaskan ketimpangan, interaksi, dan struktur spasial wilayah yang optimal antardistrik dengan menggunakan peubah yang terdiri atas infrastruktur, fasilitas publik dalam kegiatan nasional dan pusat aktivitas distrik dan pusat-pusat kegiatan. Penelitian ini menggunakan model analisis skalogram dan gravitasi. Hasil penelitian ini menunjukkan bahwa tingkat ketimpangan pembangunan antardistrik di Timor-Leste sangat tinggi disebabkan kurangnya fasilitas publik dan kurangnya akses pelayanan umum. Disamping itu, interaksi struktur spasial antardistrik sangat rendah dan lemah. Penelitian ini juga merumuskan Pusat Kegiatan Nasional di bagian Utara (Dili) dan tiga Pusat Kegiatan Wilayah yaitu Ermera di bagian Barat, Baucau di bagian Timur dan Manufahi di bagian Selatan Timor-Leste.
\end{abstract}

Kata kunci: interaksi spasial, ketimpangan wilayah, model gravitasi, skalogram, struktur spasial 


\section{PENDAHULUAN}

\section{Latar Belakang}

Pembangunan adalah suatu proses multidimensi yang melibatkan berbagai perubahan mendasar dalam struktur sosial, tingkah laku sosial dan institusi sosial, disamping akselerasi pertumbuhan ekonomi, pengurangan ketimpangan pendapatan, serta pemberantasan kemiskinan (Todaro dan Smith, 2012). Tujuan dari pembangunan adalah untuk meningkatkan kesejahteraan masyarakat secara merata. Oleh karena itu, dalam pembangunan diperlukan pertumbuhan ekonomi yang meningkat, disertai dengan distribusi pendapatan yang merata. Seperti yang disampaikan oleh Santosa (2015), pertumbuhan ekonomi dan pemerataan ekonomi merupakan dua tujuan pembangunan yang seharusnya dapat dicapai secara bersamaan dalam proses pembangunan ekonomi.

Pertumbuhan ekonomi tanpa diikuti oleh pemerataan ekonomi akan memperlebar jurang pemisah antara satu kelompok masyarakat dan kelompok lainnya, sementara pemerataan ekonomi tanpa pertumbuhan ekonomi sama halnya dengan meningkatkan kemiskinan suatu daerah (Rubiarko, 2013). Demikian juga menurut pendapat Rustiadi et al. (2011), pembangunan yang hanya menekankan pada pertumbuhan ekonomi dan pendapatan per kapita akan menimbulkan persoalan pembangunan yang kompleks. Dalam skala nasional, pertumbuhan ekonomi yang cepat namun tidak diimbangi dengan pemerataan, akan menimbulkan ketimpangan wilayah. Ketimpangan wilayah (regional disparity) tersebut juga diikuti oleh ketimpangan tingkat pertumbuhan penduduk serta terjadinya perbedaan struktur ekonomi (Nurhuda dan Prasetyo, 2011). Ketimpangan pembangunan antardaerah dapat dilihat dari kesenjangan dalam pendapatan per kapita, kualitas sumber daya manusia, ketersediaan sarana dan prasarana dan akses ke perbankan (Candra et al., 2010).

Pembangunan merupakan permasalahan yang kompleks, sesuai pernyataan Acemoglu dan Robinson (2012) yang menjawab sekaligus mengajukan pertanyaan atas isu strategis di dunia, wilayah dan negara manapun yaitu: (1) kenapa (why) ada negara yang kaya dan lainnya tidak? (2) kenapa negara gagal (why nations fail)? (3) kenapa ada negara yang gagal untuk membangun dan ada negara yang berhasil membangun? (4) kenapa ada negara yang miskin dalam sumber daya alam potensial dan ada negara yang kaya dalam sumber daya alam yang terbatas bahkan kecil? (5) kenapa kemiskinan dan ketimpangan terjadi secara spasial antarwilayah, lokal dan antarnegara? dan (6) berkaitan dengan keempat pertanyaan terdahulu adalah: kenapa ada negara yang maju dan berhasil dalam pembangunan melalui penataan-kembali kelembagaan (institutional re-arrangements) sementara negara lain tidak? kenapa dan kenapa (why and why)?

Ketimpangan wilayah dicirikan oleh perbedaan tingkat perkembangan aktivitas ekonomi dan sosial masyarakatnya. Aktivitas masyarakat tersebut, bergantung pada ketersediaan fasilitas pendukung ekonomi (seperti bank dan pasar), fasilitas layanan sosial (sekolah, rumah sakit dan lainnya), fasilitas layanan administrasi pemerintah, serta infrastruktur (jalan, alat transportasi dan sebagainya). Oleh karena itu, keterjangkauan masyarakat terhadap fasilitas-fasilitas tersebut, menentukan tingkat pelayanan yang bisa diakses, sehingga menentukan kesejahteraan masyarakat.

Tolok ukur keberhasilan pembangunan dapat dilihat dari pertumbuhan ekonomi dan semakin kecilnya ketimpangan pendapatan antarpenduduk, antardaerah dan antarsektor. Akan tetapi pada kenyataannya pertumbuhan ekonomi tidak selamanya diikuti pemerataan secara memadai. Ketimpangan antar daerah seringkali menjadi masalah serius. Beberapa daerah mencapai pertumbuhan cepat, sementara beberapa daerah lain mengalami pertumbuhan yang lambat. Daerah-daerah tersebut tidak mengalami kemajuan yang sama disebabkan beberapa hal misalnya karena kurangnya sumber-sumber yang dimiliki, adanya kecenderungan penanam modal (investor) 
memilih daerah perkotaan atau daerah yang telah memiliki fasilitas seperti prasarana perhubungan, jaringan listrik, jaringan telekomunikasi, juga tenaga kerja yang terampil (Kurniasih, 2013).

Ketimpangan pembangunan seringkali menjadi permasalahan serius dan apabila tidak mampu dieliminasi secara hati-hati dapat menimbulkan krisis yang lebih kompleks seperti masalah kependudukan, ekonomi, sosial, politik dan lingkungan, serta dalam konteks makro sangat merugikan proses dan hasil pembangunan yang ingin dicapai suatu wilayah (Mopangga, 2011). Sebagai salah satu contoh, di negara India tingkat pertumbuhan ekonomi terjadi tidak seimbang dan inklusif. Oleh sebab itu, negara tersebut memiliki tingkat ketimpangan wilayah yang sangat tinggi dan penyebaran kebutuhan ekonomi yang tidak merata karena berbanding terbalik dengan tingkat keseimbangan ekonomi (Raman dan Kumari, 2012).

Perspektif pembangunan spasial di Eropa mengadopsi berbagai paket strategi kebijakan yang mengintegrasikan tentang ketimpangan ekonomi dan meningkatkan ekonomi yang kompetitif. Peningkatan ekonomi dan pengurangan ketimpangan dapat dilakukan melalui peningkatan infrastruktur dan fasilitas yang lengkap serta memadai untuk meningkatkan aktivitas ekonomi baru (Dewar dan Epstein, 2007).

Menurut Andrade dalam Misra et al. (1978) dalam bukunya Regional Planning and National Development, seluruh pelayanan jasa pada suatu wilayah (region) harus terletak pada lokasi akses yang mudah, tepat dan sesuai pilihan (convenient choices location) populasi ketika mereka ditunjuk untuk dilayani (designed to serve) melalui jalan lintasan dan koridor (passage) fasilitas tambahan untuk memperbaiki akses konsumen dan jasa-jasa pelayanan.

Timor-Leste merupakan suatu negara yang baru merdeka pada tahun 2002. Pembangunan masih terkonsentrasi pada distrik tertentu, terutama Kota Dili. Kesenjangan antara distrik termaju (Dili) dengan distrik terbelakang relatif masih tinggi. Ketimpangan antardistrik tersebut, perlu dikurangi melalui pembangunan fasilitas di distrik yang dijadikan sebagai pusat pertumbuhan. Pemilihan distrik sebagai pusat pertumbuhan sangat penting agar investasi pembangunan fasilitas dapat dijangkau oleh masyarakat banyak dan dapat memberikan multiplier effect yang besar. Penelitian ini bertujuan untuk menganalisis ketimpangan pembangunan antar distrik di Timor-Leste serta interaksi struktur spasial antar distrik di Timor-Leste dan merumuskan susunan hierarki.

Ketimpangan memiliki dampak positif maupun dampak negatif. Dampak positif dari adanya ketimpangan adalah dapat mendorong wilayah lain yang kurang maju untuk dapat bersaing dan meningkatkan pertumbuhannya guna meningkatkan kesejahteraannya. Sedangkan dampak negatif dari ketimpangan yang ekstrim antara lain inefisiensi ekonomi, melemahkan stabilitas sosial dan solidaritas, serta ketimpangan yang tinggi pada umumnya dipandang tidak adil (Yeniwati, 2013).

Dili merupakan ibu kota negara TimorLeste. Berbagai infrastruktur serta pusat kegiatan juga berada di daerah tersebut misalnya, lembaga keuangan, pelabuhan dan bandara. Timor-Leste memiliki tiga lembaga keuangan bank dari negara asing yaitu Bank Australian and New Zealand (ANZ), Bank Mandiri (Indonesia) dan Banco Nacional Ultramarino (BNU) salah satu bank yang dimiliki oleh Portugal. Sedangkan bank sentral yang dimiliki Timor-Leste ada dua yaitu Banco Central de Timor Leste (BCTL) dan Banco Nacional de Comercio Timor Leste (BNCTL) atau Bank Dagang Nasional. Keberadaan lembaga keuangan tersebut di Dili, menggambarkan terkonsentrasinya aktivitas yang terpusat di satu distrik dan tidak tersebar di 12 distrik lainnya. Hal ini juga disebabkan oleh banyaknya infrastruktur yang sudah terbangun di wilayah tersebut bila dibandingkan dengan distrik lainnya. Kondisi perencanaan pembangunan yang hanya terpusat pada satu distrik saja akan berdampak pada ketimpangan antar wilayah, ketimpangan antara 
perkotaan dengan perkotaan dan antara perdesaan dengan perdesaan.

Ketimpangan wilayah yang terjadi salah satunya belum memiliki institusi perencanaan pembangunan di masing-masing daerah yaitu Badan Perencanaan Pembangunan Daerah (BAPPEDA), karena institusi ini yang menyusun rencana tata ruang daerah. Oleh karena itu penelitian yang dimaksudkan untuk mengetahui ketimpangan dan interaksi struktur spasial pembangunan wilayah di Timor-Leste sangat diperlukan. Tujuan dari penelitian ini, antara lain: (1) mengkaji dan menganalisis ketimpangan (disparity) pembangunan antarwilayah di Timor-Leste, (2) mengkaji dan menganalisis keterkaitan dan interaksi spasial antardistrik di Timor-Leste, (3) merumuskan tentang perwilayahan pengembangan wilayah Pusat Kegiatan Nasional (PKN) dan Pusat Kegiatan Wilayah (PKW) berbasis struktur spasial.

\section{METODE PENELITIAN}

Data yang digunakan dalam penelitian ini adalah data sekunder. Data diperoleh dari Timor Leste dalam Angka (2010, 2011, 2013), laporan dari instansi terkait dan hasil penelitian terdahulu. Data yang digunakan diantaranya data jumlah penduduk, jenis dan jumlah fasilitas di tiap distrik, jarak antar kota, moda transportasi dan biaya transport. Analisis data menggunakan metode analisis skalogram dan analisis gravitasi.

\section{Metode Analisis Skalogram}

Metode analisis skalogram digunakan untuk mengetahui ketimpangan antarwilayah. Metode ini mengurutkan dan memberi peringkat pada distrik dan juga fasilitas berdasarkan nilai indeks skalogram. Penelitian ini menggunakan dua jenis skalogram yaitu skalogram-1 (dengan 4 peubah) dan skalogram2 (dengan 27 peubah). Peubah skalogram-1 adalah sekolah, rumah sakit, bank dan pasar. Skalogram-2 menggunakan peubah jumlah sekolah dasar, sekolah menengah, sekolah lanjutan, rumah sakit umum, community health center, health post, sisca (pelayanan kesehatan keliling), private clinic, bank, pelabuhan, telepon, radio, $\mathrm{TV}$, total aset rumah tangga, kendaraan bermotor, motor, sepeda, traktor, rice husker, rice mill, pasar, kantor pos, terminal, gereja, toko/supermarket, bandara dan Kamar Dagang dan Industri (KADIN).

Tahapan dalam menyusun indeks skalogram:

Menghitung indeks fasilitas per 1,000 penduduk

Dimana:

$$
A_{i j}=1,000 * \frac{F_{i j}}{P_{i}}
$$

$\mathrm{A}_{\mathrm{ij}}=$ indeks fasilitas ke-j pada distrik ke- $\mathrm{i}$

$F_{i j}=$ jumlah fasilitas ke-j pada distrik ke-i

$\mathrm{P}_{\mathrm{i}}=$ jumlah penduduk pada distrik ke-i

Menghitung invers indeks data: $A_{i j}=1 / X_{i j}$

Menghitung bobot indeks penciri:

$$
\begin{aligned}
& \quad I_{i j}=\frac{X_{i j} n}{X_{\cdot j} a_{j}} \\
& \quad \text { dimana: } \\
& \mathrm{i}=\text { distrik ke-i } \\
& \mathrm{n}=\text { jumlah distrik } \\
& \mathrm{j}=\text { fasilitas ke- } \mathrm{j} \\
& \mathrm{a}_{\mathrm{j}}=\text { jumlah seluruh variabel penciri }
\end{aligned}
$$

Melakukan pembakuan indeks untuk seluruh variabel sehingga hasil akhir sebagai berikut:

$$
\begin{aligned}
& K_{i j}=X_{i j}-\min X_{j} S_{j} \\
& \text { Sehingga } \\
& \sum_{j}^{n} \begin{array}{c}
K_{i j} \text { adalah jumlah model } \\
\text { perkembangan wilayah }
\end{array}
\end{aligned}
$$

Mengkelaskan distrik:

Hierarki 1: $\sum K_{i j}>$ Rataan $\left(K_{i j}\right)+S D\left(K_{i j}\right)$

Hierarki 2: $\left(K_{i j}\right)<\sum K_{i j}<$ Rataan $\left(K_{i j}\right)+$

$$
S D\left(K_{i j}\right)
$$

Hierarki 3: $\sum K_{i j}<$ Rataan $\left(K_{i j}\right)$

$$
\text { Jumlah Indeks per wilayah } \sum_{j}^{n} K_{i j}=K_{i}
$$

\section{Model Analisis Gravitasi}

Model gravitasi digunakan untuk interaksi antar distrik. Dengan model ini dapat dilihat pengaruh dari distrik yang satu dengan yang lainnya. Data yang digunakan adalah 
jumlah penduduk distrik asal $\left(\mathrm{P}_{\mathrm{i}}\right)$, jumlah penduduk distrik tujuan $\left(\mathrm{P}_{\mathrm{j}}\right)$ dan jarak distrik asal ke distrik tujuan $\left(\mathrm{d}_{\mathrm{ij}}\right)$. Tahapan model gravitasi dirumuskan sebagai berikut:

$$
\begin{aligned}
& \text { Angka Interaksi }(A i j)=k \frac{P_{i} \times P_{j}}{d_{i j}{ }^{2}} \\
& \text { Nilai Interaksi (satuan daya tarik) } \\
& =\sum_{1}^{n} A_{i j} \\
& \text { Rata-rata nilai interaksi } \\
& =\frac{\text { Nilai interaksi (satuan daya tarik) }}{\mathrm{n}-1} \\
& \text { Dimana: } \\
& \qquad \mathrm{A}_{\mathrm{ij}}=\text { angka interaksi } \\
& \mathrm{K} \quad=\text { diasumsikan dengan } 1 \\
& \mathrm{j} \quad=\text { distrik tujuan } \\
& \mathrm{P}_{\mathrm{i}} \quad=\text { penduduk distrik asal } \\
& \mathrm{P}_{\mathrm{j}} \quad=\text { penduduk distrik tujuan } \\
& \mathrm{d}_{\mathrm{ij}} \quad=\text { jarak dari distrik asal ke tujuan } \\
& \mathrm{d}_{\mathrm{ij}}{ }^{2}=\text { kuadrat dari jarak }
\end{aligned}
$$

Menghitung indeks:

Indeks $=\frac{\text { nilai interaksi dari Dili ke distrik lain yang terbesar }}{\text { nilai interaksi dari Dili ke distrik lain yang terkecil }}$

\section{Merumuskan dan Mengklasifikasi Pengembangan Pusat Kegiatan Nasional (PKN) dan Pusat Kegiatan Wilayah (PKW) berbasis Struktur Spasial}

Dalam tahap merumuskan dan mengklasifikasi pengembangan wilayah, yaitu menggunakan analisis kualitatif dari hasil metode sebelumnya. Analisis kualitatif yang digunakan dalam penelitian ini yaitu merumuskan sintesis struktur/ordo (pusat-pusat kegiatan) struktur jaringan antar kegiatan per wilayah pembangunan. Penyusunan hierarki atau pusat-pusat kegiatan bertujuan mengetahui kondisi ketimpangan infrastruktur yang terjadi di Timor-Leste. Untuk merumuskan dan mengklasifikasikan hierarki diperlukan analisis skalogram dan analisis gravitasi. Setelah mendapatkan hasil dari penghitungan dengan dua metode maka selanjutnya yaitu merumuskan hierarki atau orde dengan menggunakan data jumlah penduduk, kepadatan penduduk, jumlah fasilitas, jarak dari beberapa distrik ke Dili. Selain itu, diperlukan juga memasukkan interaksi wilayah. Interaksi wilayah digunakan untuk mengetahui jumlah urutan daerah yang memiliki fasilitas paling tinggi berdasarkan rumus yang telah ditentukan.

Tujuan dari rumusan atau klasifikasi ini untuk menentukan distrik yang termasuk dalam tiga kategori. Tiga kategori tersebut meliputi Pusat Kegiatan Nasional (PKN), Pusat Kegiatan Wilayah (PKW) dan distrik sebagai hinterland. Pusat Kegiatan Nasional merupakan daerah yang memiliki pusat aktivitas terpadat dan mampu menjadi penyedia fasilitas bagi distrik lain. Pusat Kegiatan Wilayah merupakan pusat penyedia kegiatan maupun fasilitas bagi wilayah hinterland. Hinterland merupakan daerah-daerah terbelakang yang bergantung pada distrik sebagai PKN maupun PKW. Hinterland biasanya menyebabkan menurunnya kapasitas produksi kegiatan ekonomi, terutama laju pertumbuhan penduduknya tidak seimbang dengan laju pertumbuhan kapasitas produksi kawasan.

\section{HASIL DAN PEMBAHASAN}

\section{Analisis Disparitas Spasial Antarwilayah}

Ketimpangan pembangunan memang merupakan salah satu hal penting yang harus diperhatikan oleh Pemerintah dan komponen masyarakat (Barika, 2012). Ketimpangan merupakan suatu kondisi yang tidak seimbang antara distrik yang satu dengan distrik yang lain.

Hierarki 1 merupakan distrik dengan tingkat perkembangan paling maju, dicirikan oleh indeks distrik paling tinggi dan ditentukan oleh jumlah ketersediaan sarana dan prasarana yang cukup memadai. Hierarki 2 merupakan distrik dengan tingkat perkembangan sedang ditunjukkan oleh tingkat sarana dan prasarana yang tersedia di distrik tersebut lebih sedikit dari Hierarki 1. Hierarki 3 ditunjukkan oleh tingkat sarana dan prasarana yang tersedia di distrik tersebut relatif sangat kurang dan jarak dari masing-masing distrik terhadap pusatpusat pelayanan relatif jauh sehingga untuk mengakses pusat-pusat pelayanan relatif lebih sulit dibandingkan dengan distrik yang ada pada hierarki 1 dan hierarki 2. 
Tabel 1. Hierarki distrik berdasarkan hasil analisis skalogram-1

\begin{tabular}{|c|c|c|c|c|c|c|c|c|}
\hline \multirow[b]{2}{*}{ Distrik } & \multicolumn{5}{|c|}{ Variabel A } & \multirow{2}{*}{$\begin{array}{c}\text { Jumlah Indeks } \\
\text { per Distrik } \\
\left(\sum_{j}^{n} K i j\right)\end{array}$} & \multirow[b]{2}{*}{ Peringkat } & \multirow[b]{2}{*}{ Hierarki } \\
\hline & Penduduk & Sekolah & $\begin{array}{c}\text { Rumah } \\
\text { Sakit }\end{array}$ & Bank & Pasar & & & \\
\hline Dili & 266,236 & 1.606 & 0.064 & 3.464 & 3.822 & 8.957 & 1 & Hierarki 1 \\
\hline Baucau & 116,934 & 3.446 & 3.085 & 0.000 & 1.274 & 7.806 & 2 & Hierarki 1 \\
\hline Covalima & 62,303 & 0.993 & 2.314 & 0.000 & 1.699 & 5.006 & 3 & Hierarki 2 \\
\hline Bobonaro & 96,271 & 2.424 & 0.836 & 0.000 & 1.274 & 4.534 & 4 & Hierarki 2 \\
\hline Viqueque & 72,797 & 1.285 & 1.671 & 0.000 & 0.849 & 3.806 & 5 & Hierarki 2 \\
\hline Ermera & 124,687 & 2.015 & 0.836 & 0.000 & 0.849 & 3.700 & 6 & Hierarki 2 \\
\hline Liquica & 67,831 & 0.643 & 1.928 & 0.000 & 0.000 & 2.571 & 7 & Hierarki 3 \\
\hline Manatuto & 45,098 & 0.467 & 0.321 & 0.000 & 1.274 & 2.063 & 8 & Hierarki 3 \\
\hline Ainaro & 63,121 & 0.789 & 0.450 & 0.000 & 0.425 & 1.663 & 9 & Hierarki 3 \\
\hline Manufahi & 51,904 & 0.409 & 0.321 & 0.000 & 0.425 & 1.155 & 10 & Hierarki 3 \\
\hline Aileu & 47,643 & 0.497 & 0.000 & 0.000 & 0.425 & 0.921 & 11 & Hierarki 3 \\
\hline Lautem & 65,475 & 0.000 & 0.321 & 0.000 & 0.425 & 0.746 & 12 & Hierarki 3 \\
\hline
\end{tabular}

Sumber: Data diolah, 2016.

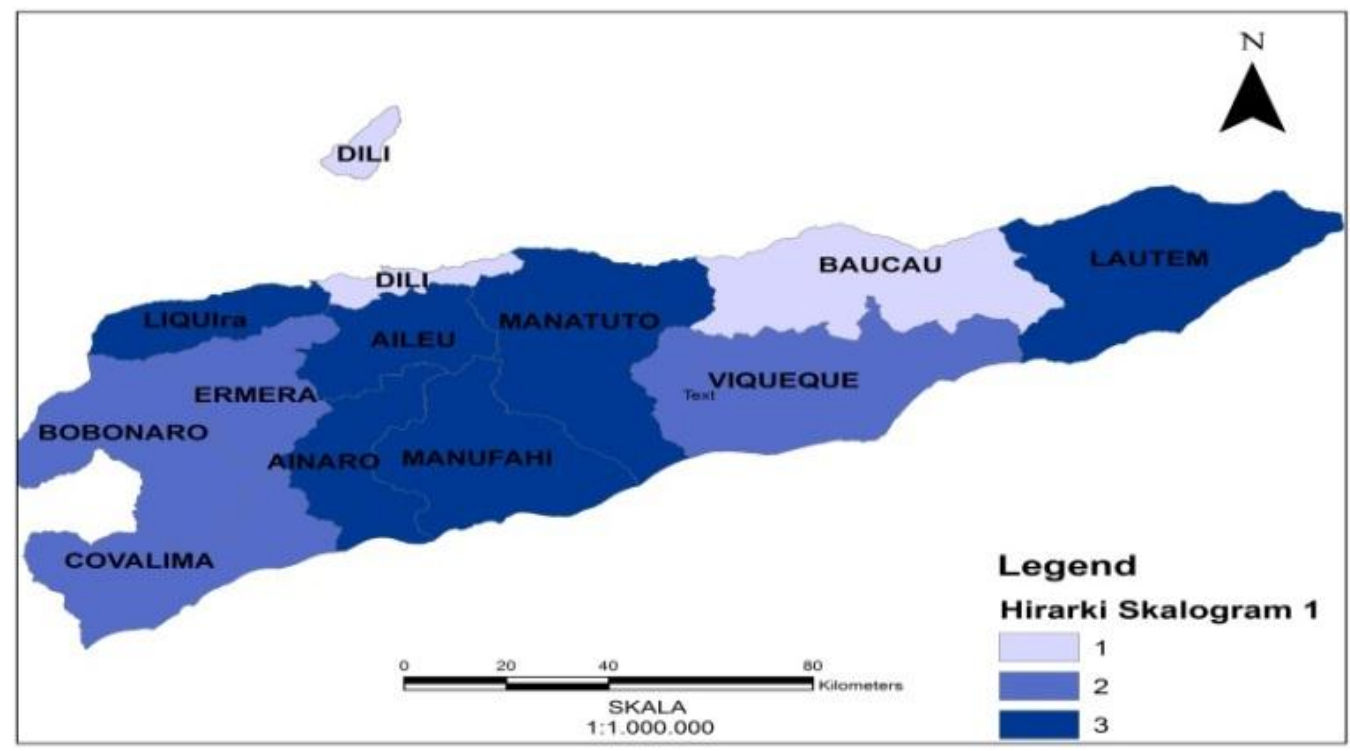

Gambar 1. Peta Hierarki Skalogram 1 Sumber: Data diolah, 2016.

Hasil analisis skalogram-1 [Tabel 1] yang menggunakan peubah sekolah, rumah sakit, bank, dan pasar menunjukkan bahwa Dili menduduki peringkat 1 . Peringkat 2 ditempati oleh Distrik Baucau. Artinya, bahwa keempat prasarana dan sarana di Distrik Dili dan Distrik Baucau cukup tersedia dan lengkap. Baucau merupakan distrik terbesar kedua di TimorLeste dan mempunyai fasilitas umum seperti sekolah, rumah sakit, bank dan pasar. Di Baucau juga terdapat pendidikan teknik dan pendidikan tinggi. Universitas dan sekolah kejuruan di Baucau mempunyai kualitas terbaik karena pengelola pendidikan adalah para misionaris Katolik di Timor-Leste.

Distrik pada hierarki 1 (Dili dan Baucau) juga memiliki jumlah penduduk paling padat, disamping jumlah fasilitas yang cukup tinggi. Hal ini dapat dilihat pada jumlah indeks masing-masing peubah, jumlah indeks distrik yang tinggi yaitu sebesar 8.957 untuk Distrik Dili dan 7.806 untuk Distrik Baucau. Hasil analisis Skalogram-2 dapat dilihat pada Tabel 2 . 
Tabel 2. Hasil analisis metode skalogram 2

\begin{tabular}{lccc}
\hline Distrik & $\begin{array}{c}\text { Jumlah Indeks per } \\
\text { Wilayah }\end{array}$ & Peringkat & Hierarki \\
\hline Dili & 506.09 & 1 & Hierarki 1 \\
Lautem & 413.39 & 2 & Hierarki 2 \\
Covalima & 401.67 & 3 & Hierarki 2 \\
Baucau & 397.78 & 4 & Hierarki 2 \\
Bobonaro & 387.93 & 5 & Hierarki 2 \\
Viqueque & 385.04 & 6 & Hierarki 2 \\
Manufahi & 372.21 & 7 & Hierarki 3 \\
Liquica & 361.88 & 8 & Hierarki 3 \\
Manatuto & 345.12 & 9 & Hierarki 3 \\
Ermera & 339.71 & 10 & Hierarki 3 \\
Ainaro & 328.21 & 11 & Hierarki 3 \\
Aileu & 325.84 & 12 & Hierarki 3 \\
\hline
\end{tabular}

Sumber: Data diolah, 2016.

Distrik Dili dan Distrik Baucau yang berada pada hierarki 1 , memiliki 4 fasilitas umum terlengkap (sekolah, rumah sakit, bank dan pasar). Distrik tersebut merupakan Central Businesss District (CBD) bagi distrik di sekitarnya. Pusat kota atau pusat bisnis merupakan lokasi yang paling menarik bagi perusahaan dan rumah tangga (Capello, 2007), sehingga dua distrik tersebut selalu menjadi pusat perhatian bagi daerah lain. Selain itu, Dili dan Baucau menjadi motor penggerak pertumbuhan ekonomi dan kontribusi bagi pertumbuhan ekonomi daerah lain yang memiliki hierarki lebih rendah (hierarki 2 dan hierarki 3). Distrik yang termasuk hierarki 2 adalah Distrik Bobonaro, Covalima, Ermera, dan Viqueque. Sedangkan distrik yang termasuk hierarki 3 adalah Aileu, Ainaro, Liquica, Lautern, Manufahi, dan Manatuto. Lautem merupakan distrik dengan fasilitas paling minim di Timor-Leste, dapat dilihat dari indeks hierarki distrik tersebut yang paling rendah di antara distrik-distrik lainnya.
Analisis skalogram-2 menggunakan 27 peubah yang terdiri atas 4 peubah yang digunakan pada skalogram-1, ditambah dengan 23 peubah baru. Peubah yang digunakan tersebut meliputi jumlah fasilitas publik yang ada di Timor Leste yaitu fasilitas pendidikan, fasilitas kesehatan, fasilitas transportasi dan fasilitas pertanian.

Skalogram dengan menggunakan 27 peubah, distrik yang masuk dalam hierarki 1 yaitu Dili. Baucau yang semula masuk hierarki 1 (pada skalogram-1), dengan 27 peubah (skalogram-2) menjadi hierarki 2. Bahkan posisi peringkat Baucau (peringkat 4) berada di bawah Distrik Lautem (peringkat 2) dan Distrik Covalima (peringkat 3). Berarti kelengkapan fasilitas publik yang ada di Baucau masih kurang dibandingkan dengan Lautem dan Covalima. Secara spasial hasil skalogram-2 ditunjukkan pada Gambar 2. 


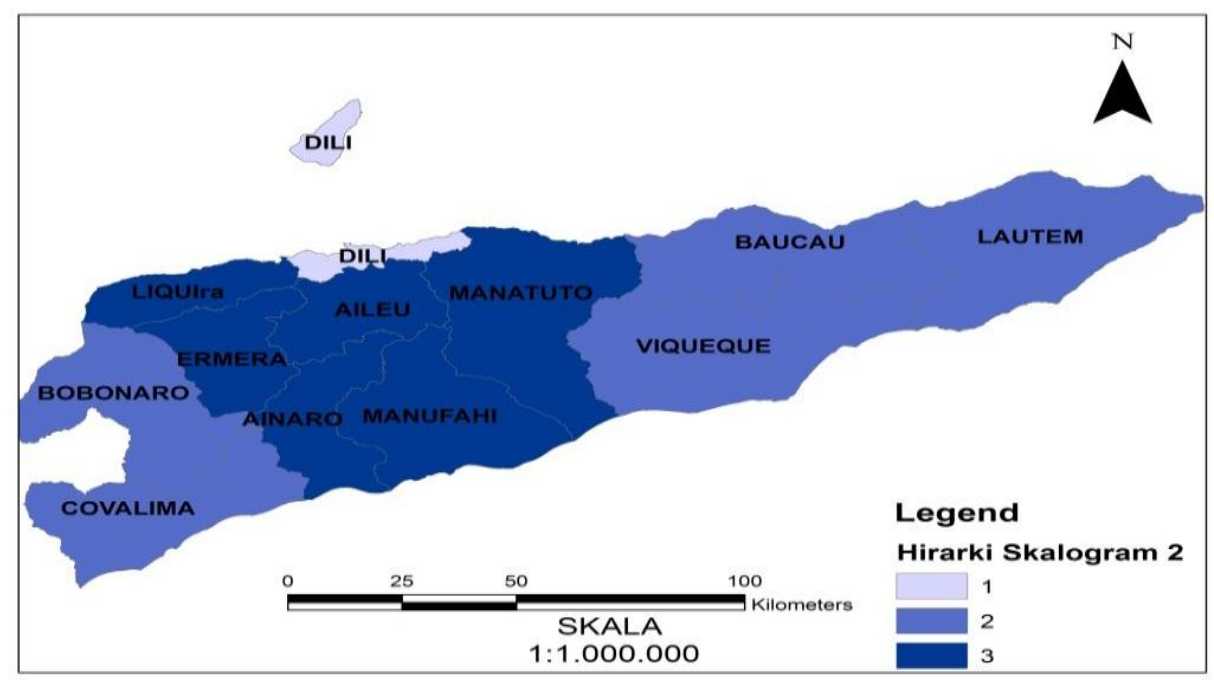

Gambar 2. Peta Hierarki Skalogram 2 Sumber: Data diolah, 2016.

Hierarki 3 dari skalogram-2 [Gambar 2] meliputi Manufahi, Liquica, Manatuto, Ermera, Ainaro dan Aileu. Fasilitas yang dimiliki oleh keenam distrik tersebut tidak lengkap dibandingkan dengan distrik lain. Fasilitas transportasi pada umumnya belum memadai, dan ditambah dengan jarak ke pusat pelayanan dan pusat-pusat kegiatan yang cukup jauh. Ermera merupakan distrik yang memiliki jumlah penduduk tertinggi di antara distrik lain yang berada pada hierarki 3. Namun jumlah penduduk yang tinggi tidak diikuti dengan ketersediaan fasilitas yang cukup, sehingga masuk dalam peringkat 10 .

\section{Analisis Interaksi dan Keterkaitan Antarwilayah}

Metode analisis gravitasi digunakan untuk memperkirakan daya tarik suatu lokasi dibandingkan dengan lokasi lain di sekitarnya.
Interaksi antar kedua lokasi dapat terlihat dari banyaknya perjalanan (trip) penduduk suatu lokasi ke lokasi lainnya. Nilai interaksi distrik berdasarkan peubah penduduk di Timor-Leste.

Berdasarkan informasi yang disajikan pada Tabel 1 menunjukkan bahwa distrik di lokasi penelitian (Timor-Leste) merupakan distrik dengan kategori perkembangan rendah. Hal ini dapat dilihat dari jumlah distrik hierarki 3 pada metode skalogram-1 dengan 4 peubah berjumlah enam distrik dari 12 distrik yang ada di Timor-Leste (Liquica, Manatuto, Ainaro, Manufahi, Aileu dan Lautem), sedangkan distrik yang masuk kategori berkembang dan maju (hierarki 1) hanya dua distrik yaitu Dili dan Baucau dan sisanya masuk kategori hierarki 2 yaitu empat distrik masing-masing Covalima, Bobonaro, Viqueque dan Ermera pada metode skalogram-1 dengan 4 peubah [lihat Tabel 3]. 
Tabel 3. Analisis gravitasi terhadap Kota Dili

\begin{tabular}{lccccc}
\hline \multicolumn{1}{c}{ Distrik } & $\begin{array}{c}\text { Jumlah } \\
\text { Penduduk Dili }\end{array}$ & $\begin{array}{c}\text { Jumlah } \\
\text { Penduduk } \\
\text { Distrik j }\end{array}$ & $\begin{array}{c}\text { Jarak Dili ke } \\
\text { Distrik j }\end{array}$ & $\begin{array}{c}\text { Interkasi } \\
\text { Distrik j ke Dili }\end{array}$ \\
\hline Dili - Liquica & 266,236 & 67,831 & 32 & $17,635,795.00$ & $\mathbf{6 2}$ \\
Dili - Ermera & 266,236 & 124,687 & 56 & $10,585,513.00$ & $\mathbf{3 7}$ \\
Dili - Aileu & 266,236 & 47,643 & 47 & $5,742,092.00$ & $\mathbf{2 0}$ \\
Dili - Ainaro & 266,236 & 63,121 & 78 & $2,762,177.00$ & $\mathbf{1 0}$ \\
Dili - Manufahi & 266,236 & 51,904 & 81 & $2,106,190.00$ & $\mathbf{7}$ \\
Dili- - Baucau & 266,236 & 116,934 & 122 & $2,091,645.00$ & $\mathbf{7}$ \\
Dili - Bobonaro & 266,236 & 96,271 & 149 & $1,154,489.00$ & $\mathbf{4}$ \\
Dili - Covalima & 266,236 & 62,303 & 139 & $858,511.50$ & $\mathbf{3}$ \\
Dili -Viqueque & 266,236 & 72,797 & 183 & $578,732.80$ & $\mathbf{2}$ \\
Dili -Lautem & 266,236 & 65,475 & 248 & $283,425.50$ & $\mathbf{1}$ \\
\hline
\end{tabular}

Sumber: Data diolah, 2016.

Tabel 3 menunjukkan bahwa interaksi antar distrik lain ke Dili paling tinggi terjadi di Dili ke Liquica. Hal ini dikarenakan jarak, waktu tempuh dan biaya transportasi di antara kedua distrik tersebut lebih rendah dibandingkan dengan distrik yang lain.
Sedangkan Lautem merupakan distrik yang paling rendah interaksi wilayahnya. Hal ini karena jarak, waktu tempuh dan biaya transportasinya lebih tinggi. Secara spasial dapat dilihat pusat-pusat kegiatan antar distrik yang ditunjukkan pada Gambar 3 .

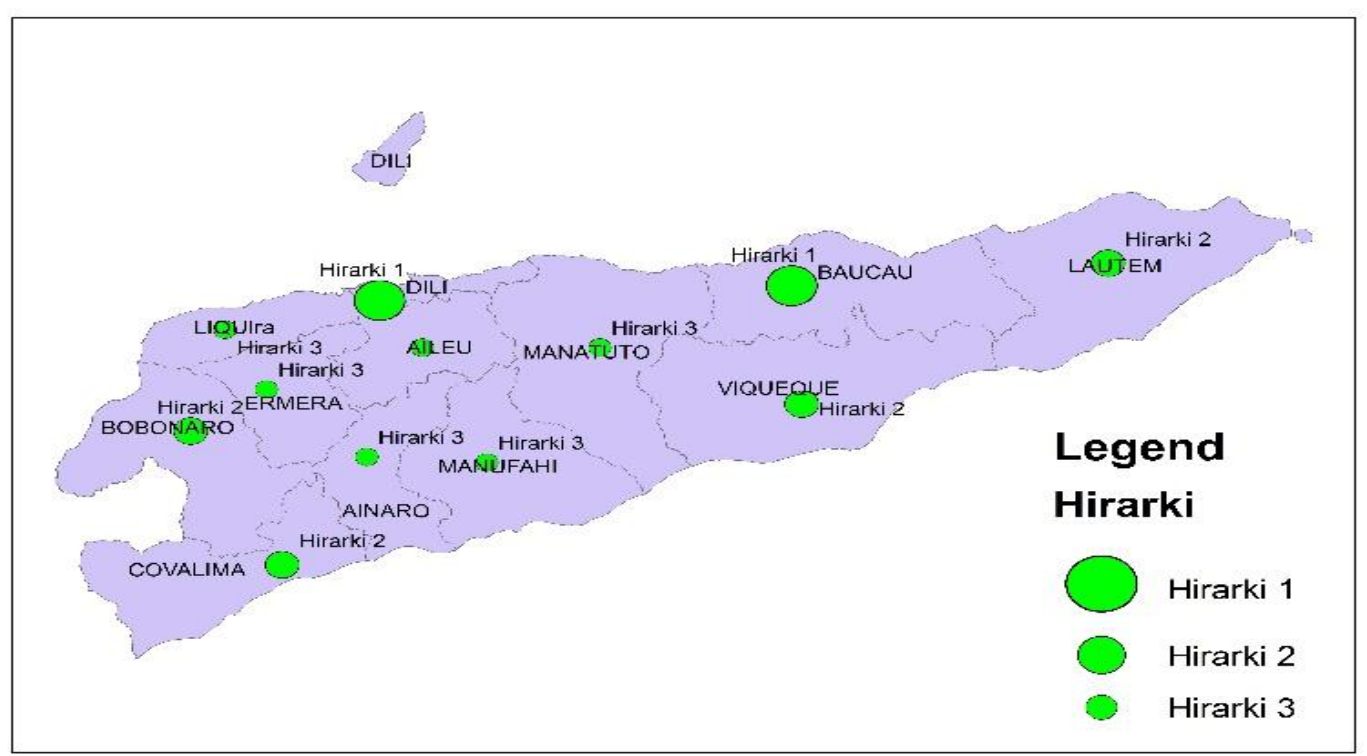

Gambar 3. Peta Hierarki PKN dan PKW baru Sumber: Data diolah, 2016.

Berdasarkan hasil analisis gravitasi menunjukkan bahwa distrik pusat pertumbuhan Dili 4,125,897.37 memiliki hubungan interaksi yang paling kuat dengan Liquica 2,049,577.31 dengan total angka Nilai Indeks Interaksi Antar Distrik (NIIAD) 6,175,474.68. Angka NIIAD masing-masing adalah sebagai berikut: Ermera 2,618,928.25 dengan Aileu 1,463,244.49 dan
Bobonaro 894,627.45 dengan total NIIAD 4,976,800.19 sehingga Ermera dapat dijadikan sebagai PKW baru untuk wilayah Tengah Timor-Leste dengan hinterland masing-masing. Baucau 750,787.26 memiliki hubungan interaksi yang kuat dengan Viqueque 421,469.44, Lautem 127,007.86 dan Manatuto $452,971.69$, dengan total NIIAD 1,752,236.25 
sehingga Baucau dapat dijadikan wilayah pengembangan PKW baru wilayah Timur Timor-Leste untuk daerah hinterland masingmasing. Distrik Manufahi 706,792.18, juga dapat dijadikan pengembangan wilayah PKW baru untuk distrik hinterland Ainaro
1,105,099.83 dan Covalima 488,621.97. Ada peluang dan potensi bagi Distrik Manufahi sebagai pengembangan PKW di wilayah Selatan Timor-Leste untuk daerah hinterland masing-masing.

Tabel 4. Analisis pengembangan Pusat Kegiatan Nasional (PKN) dan Pusat Kegiatan Wilayah (PKW) dengan distrik hinterland-nya dengan Nilai Indeks Interaksi Antar Distrik (NIIAD).

\begin{tabular}{|c|c|c|c|c|c|c|c|c|c|c|c|}
\hline 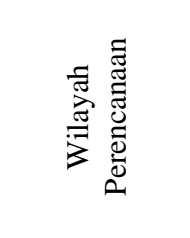 & 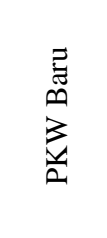 & 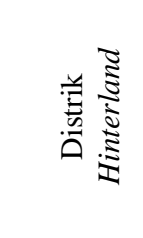 & 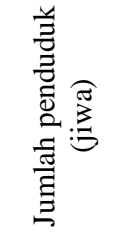 & 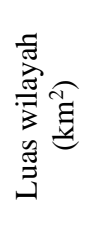 & 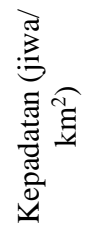 & 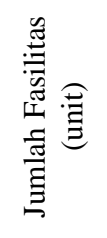 & 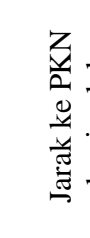 & 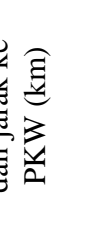 & 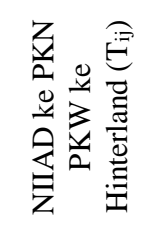 & 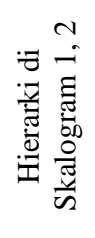 & 疋 \\
\hline 1 & 2 & 3 & 4 & 5 & 6 & 7 & $\begin{array}{c}\text { ke } \\
\text { PKN } \\
\text { (Dili) }\end{array}$ & $\begin{array}{c}\text { ke } \\
\text { PKW }\end{array}$ & 9 & 10 & 11 \\
\hline \multirow[t]{2}{*}{$\begin{array}{c}\text { Pusat } \\
\text { Pengembangan } \\
\text { Wilayah Utara }\end{array}$} & $\begin{array}{c}\text { Dili } \\
\text { (PKN) }\end{array}$ & $\begin{array}{l}\text { PKN-Dili } \\
\text { Liquica }\end{array}$ & 266,236 & 368 & 723 & 400,975 & 0 & 0 & $\begin{array}{l}4,125,897.37 \\
2,049,577.31\end{array}$ & 1,1 & $\mathrm{I}$ \\
\hline & \multicolumn{3}{|c|}{ Total NIIAD } & & & & & & $6,175,474.68$ & & \\
\hline \multirow{4}{*}{$\begin{array}{c}\text { Pusat } \\
\text { Pengembangan } \\
\text { Wilayah Barat }\end{array}$} & \multirow{3}{*}{$\begin{array}{l}\text { Ermera } \\
(\mathrm{PKW})\end{array}$} & Ermera & 124,687 & 771 & 161 & 167,044 & 56 & 0 & $2,618,928.25$ & 2,3 & II \\
\hline & & Aileu & 47,643 & 676 & 70 & 63,167 & 47 & 29 & $1,463,244.49$ & 2,3 & III \\
\hline & & Bobonaro & 96,271 & 1,381 & 69 & 133,617 & 149 & 65 & $894,627.45$ & 2,2 & III \\
\hline & \multicolumn{3}{|c|}{ Total NIIAD } & & & & & & $4,976,800.19$ & & \\
\hline \multirow{4}{*}{$\begin{array}{c}\text { Pusat } \\
\text { Pengembangan } \\
\text { Wilayah } \\
\text { Selatan } \\
\end{array}$} & \multirow{3}{*}{$\begin{array}{l}\text { Manu- } \\
\text { fahi } \\
(\mathrm{PKW})\end{array}$} & Manufahi & 51,904 & 1,786 & 39 & 71,223 & 81 & 0 & $706,792.18$ & 3,3 & II \\
\hline & & Ainaro & 63,121 & 870 & 72 & 83,838 & 78 & 60 & $1,105,099.83$ & 3,3 & III \\
\hline & & Covalima & 62,303 & 1,207 & 51 & 87,328 & 139 & 84 & $488,621.97$ & 2,2 & III \\
\hline & & Total NIIA & & & & & & & $2,300,513.98$ & & \\
\hline \multirow{5}{*}{$\begin{array}{c}\text { Pusat } \\
\text { Pengembangan } \\
\text { Wilayah } \\
\text { Timur }\end{array}$} & \multirow{4}{*}{$\begin{array}{l}\text { Baucau } \\
\text { (PKW) }\end{array}$} & Baucau & 116,934 & 1,508 & 77 & 163,448 & 122 & 0 & $750,787.26$ & 1,2 & II \\
\hline & & Manatuto & 45,098 & 1,786 & 25 & 60,662 & 87 & 60 & $452,971.69$ & 3,3 & III \\
\hline & & Lautem & 65,475 & 1,813 & 36 & 92,542 & 248 & 126 & $127,007.86$ & 3,2 & III \\
\hline & & Viqueque & 72,797 & 1,880 & 38 & 100,827 & 183 & 61 & $421,469.44$ & 2,2 & III \\
\hline & \multicolumn{3}{|c|}{ Total NIIAD } & & & & & & $1,752,236.25$ & & \\
\hline
\end{tabular}

Sumber: Data diolah, 2016. 


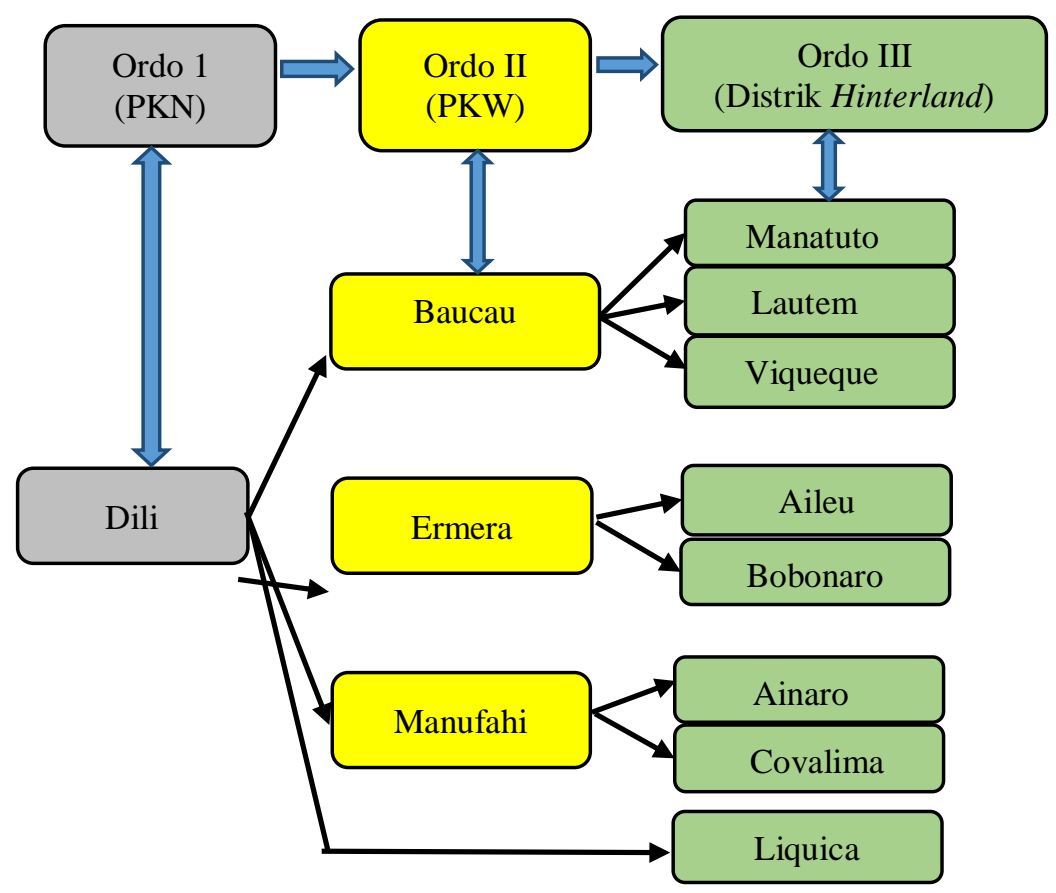

Gambar 3. Skema PKN, PKW dan distrik hinterland masing-masing

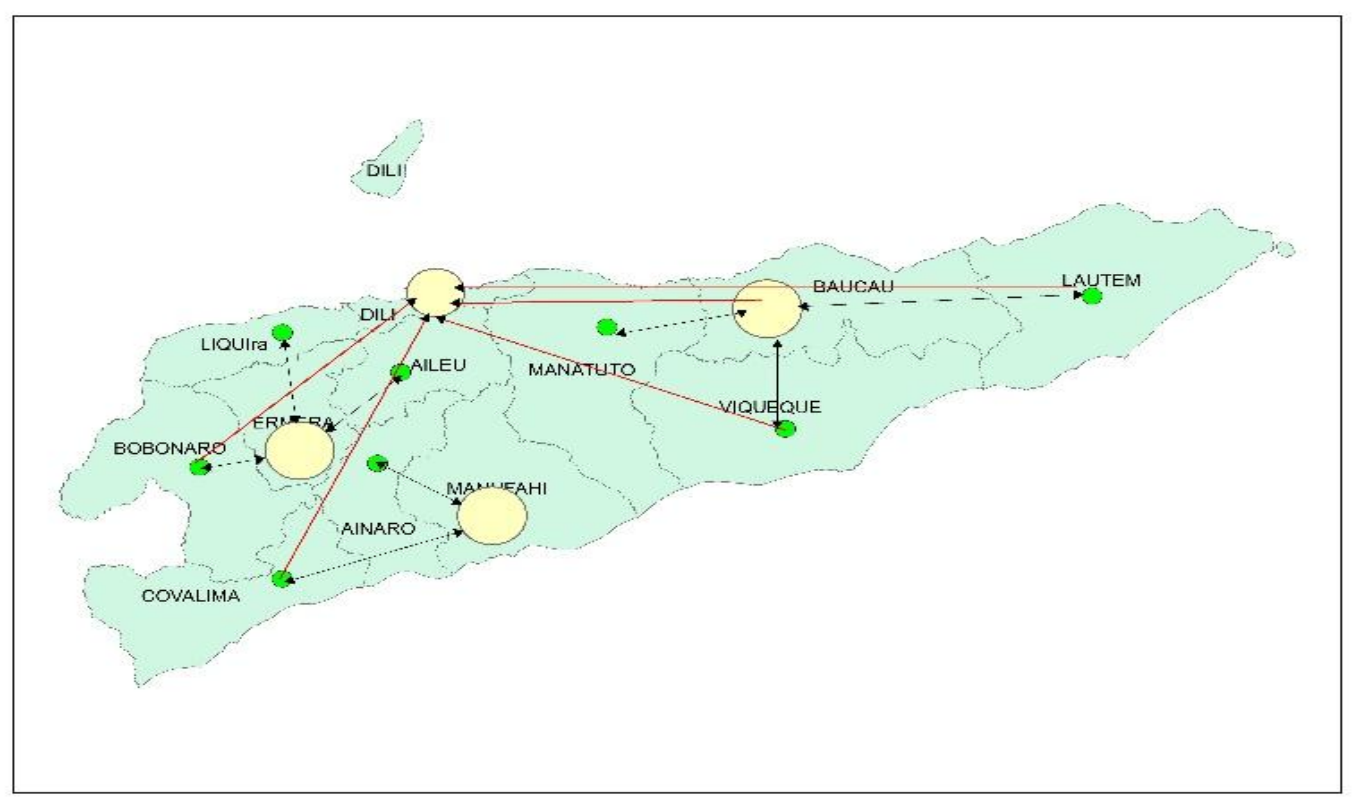

Gambar 4. Peta PKN, PKW dan distrik hinterland-nya

Distrik yang mewakili empat Pusat Kegiatan Wilayah/Nasional tersebut, sebagai CBD yang akan melayani kegiatan ekonomi distrik hinterland-nya yang secara spasial jaraknya relatif dekat. Semakin dekat jarak, interaksi hinterland dengan CBD semakin intensif seperti ditunjukkan dari hasil analisis gravitasi [Tabel 4]. Semakin tinggi interaksinya, maka kegiatan ekonomi seperti perdagangan semakin lancar, yang akhirnya dapat meningkatkan pertumbuhan ekonomi distrik hinterland. Tabel 4 menunjukkan interaksi antara distrik PKW/N dengan distrik hinterland.

\section{Pengembangan Pusat Kegiatan Wilayah}

Republik Timor-Leste merupakan kawasan yang membentang dari Timur ke Barat. Penentuan distrik sebagai pusat pertumbuhan didasarkan pada kawasan pertumbuhan yang dibagi dalam empat 
kawasan yaitu kawasan barat, timur, tengah dan kawasan selatan. Dari Tabel 3, Gambar 1, Gambar 2, dan dari 2 analisis skalogram, diketahui bahwa Dili merupakan distrik yang paling sering muncul di hierarki 1. Hal ini menunjukkan bahwa fasilitas publik di Dili terlengkap, dan bisa sebagai Pusat Kegiatan Nasional (PKN). Posisi Dili secara spasial mewakili pusat kegiatan di kawasan Barat. Di kawasan timur ada Baucau, yang juga dua kali muncul sebagai hierarki 1 dari dua analisis spasial yang dilakukan. Status Baucau sebagai hierarki 1 berfungsi sebagai PKW yang mewakili wilayah Timur.

Dari distrik yang berada di kawasan tengah, meskipun Bobonaro menempati hierarki yang sedikit lebih tinggi dibandingkan dengan Ermera, namun posisi spasial Ermera yang strategis, akan lebih menguntungkan jika Ermera sebagai PKW mewakili wilayah tengah. Sedangkan di kawasan selatan, Manufahi memiliki hierarki tertinggi dibandingkan dengan distrik lainnya, sehingga potensial sebagai PKW. Berdasarkan hasil analisis gravitasi menunjukkan bahwa distrik pusat pertumbuhan Dili 4,125,897.37 memiliki hubungan interaksi yang paling kuat dengan Liquica 2,049,577.31 dengan total NIIAD 6,175,474.68. Angka NIIAD masing-masing adalah Ermera 2,618,928.25 dengan Aileu 1,463,244.49 dan Bobonaro 894,627.45 dengan total NIIAD 4,976,800.19 sehingga Ermera sebagai PKW baru untuk wilayah Tengah dengan hinterland masing-masing. Baucau 750,787.26 memiliki hubungan interaksi yang kuat dengan Viqueque 421,469.44, Lautem 127,007.86 dan Manatuto 452,971.69. Dengan total NIIAD Baucau 1,752,236.25 dapat dijadikan wilayah pengembangan PKW baru wilayah Timur Timor-Leste untuk daerah hinterland-nya masing-masing. Distrik Manufahi 706,792.18, juga dapat dijadikan pengembangan wilayah PKW baru untuk distrik hinterland Ainaro 1,105,099.83 dan Covalima 488,621.97, Distrik Manufahi ada peluang dan potensi pengembangan PKW di wilayah Selatan untuk daerah hinterland masing-masing.

\section{KESIMPULAN DAN SARAN}

\section{Kesimpulan}

Berdasarkan hasil analisis skalogram-1, analisis skalogram-2 dan pembahasan di atas, dapat diambil kesimpulan bahwa tingkat perkembangan distrik dan antardistrik di Timor-Leste secara umum masih menunjukkan tingkat ketimpangan spasial antar daerah. Sejumlah 12 dari keseluruhan 13 distrik memiliki tingkat perkembangan yang rendah, interaksi dan keterkaitan struktur spasial yang lemah. Sebagian besar distrik masih memiliki disparitas spasial yang tinggi, baik fasilitas publik (jumlah fasilitas pendidikan, jumlah fasilitas kesehatan, dan jumlah fasilitas perekonomian), aksesibilitas (jarak) yang jauh antar wilayah yang satu dengan yang lainnya dari pusat (Dili), serta memiliki biaya yang cukup besar. Hasil tersebut dijadikan pertimbangan untuk menentukan distrik sebagai pusat pertumbuhan untuk mengurangi masalah ketimpangan antar distrik di TimorLeste.

\section{Saran dan Rekomendasi Kebijakan}

Berdasarkan hasil analisis ketimpangan dan interaksi spasial yang merupakan dasar kebijakan dan sekaligus merupakan alat (tools) dalam mencapai tujuan (goals) umum, penelitian ini dapat menjadi masukan dan saran rekomendasi yang mempunyai implikasi kebijakan publik bagi para pemimpin politik, profesional dan para perencana (PPP) untuk pembuat dan pengambil keputusan (decisionmaker), maupun masukan bagi penelitian selanjutnya berdasarkan hasil temuan dalam pada penelitian ini. Perlu political will dalam pembangunan wilayah (distrik) berbasis analisis ketimpangan dan keterkaitan struktur spasial dalam segitiga perencanaan pembangunan yaitu: Perencanaan Spasial Stratejik (PSS), Perencanaan Pembangunan Stratejik (PPS) dan Perencanaan Anggaran Stratejik (PAS), melibatkan partisipasi masyarakat dan semua stakeholder termasuk PPPs dan KADIN. 


\section{DAFTAR PUSTAKA}

Acemoglu, D., and Robinson, J. A. (2012). Why Nations Fail. The Origins of Power, Prosperity, and Poverty. New York Times.

Barika. (2012). Analisis Ketimpangan Pembangunan Wilayah Kabupaten/Kota di Provinsi Bengkulu Tahun 2005-2009. Jurnal Ekonomi dan Perencanaan Pembangunan, 4 (3). ISSN: 1979-7338.

Candra, A. K., Tunjung, W. S., \& Surjono. (2010). Kajian Disparitas Sebagai Solusi Dalam Penentuan Pemilihan Kecamatan Baru Kota Pasuruan. Jurnal Tata Kota dan Daerah, 2 (2).

Dewar, M., \& Epstein, D. (2007). Planning for Megaregions in the United States. Journal of Planning Literature, 22 (2).

Firedmann, J., \& Alonso, W. (1975). Regional Policy. Readings in Theory and Applications. Massachusetts Institute of Technology.

Kurniasih, E. P. (2013). Ketimpangan Wilayah di Provinsi Kalimantan Barat Suatu Kajian terhadap Hipotesis Kuznet. Jurnal Eksos 9 (1). ISSN 1693-9093.

Mopangga, H. (2011). Analisis Ketimpangan Pembangunan dan Pertumbuhan Ekonomidi Provinsi Gorontalo. Trikonomika, 10 (1), 4051.

Nurhuda \& Prasetyo. (2011). Analisis Ketimpangan Pembangunan (Studi Di Provinsi Jawa Timur Tahun 2005-2011). JAP 1 (4): 110-119.

Raman, R., \& Kumari, R. (2012). Regional Disparity in Agricultural Development: A District-Level Analysis For Uttar Pradesh. Journal of Regional Development and Planning, 1 (2).

Rubiarko, S. I. (2013). Analisis Faktor-Faktor yang Mempengaruhi Disparitas Pendapatan di Provinsi Jawa Timur Tahun 2008-2011. Jurnal Ilmiah, Fakultas Ekonomi Bisnis. Universitas Brawijaya.

Rustiadi, E., Saefulhakim, S., \& Panuju, D. R. (2011). Perencanaan dan Pengembangan Wilayah. Cetakan Ketiga. Yayasan Pustaka Obor Indonesia.

Santosa, S. H. (2015). Disparitas Pertumbuhan Ekonomi Dan Pembangunan Ekonomi Wilayah Di Satuan Wilayah Pembangunan IV Propinsi Jawa Timur. Media Trend 10 (2), 116-128.

Statistics Timor-Leste. 2010, 2011, 2012, 2013.
Todaro, M. P., \& Smith, S. C. (2012). Economic Development, $11^{\text {th }}$ Edition. New Work University.

Yeniwati. (2013). Ketimpangan Ekonomi antar Provinsi di Sumatera. Jurnal Kajian Ekonomi, 2 (3). 